\begin{tabular}{|l|l|l|}
\hline \multicolumn{2}{|c|}{ PublisherInfo } \\
\hline \hline PublisherName & $:$ & BioMed Central \\
\hline \hline PublisherLocation & $:$ & London \\
\hline \hline PublisherImprintName & $:$ & BioMed Central \\
\hline \hline
\end{tabular}

\title{
ATM, telomeres and aging
}

\begin{tabular}{|l|l|l||}
\hline \multicolumn{2}{|c|}{ ArticleInfo } \\
\hline \hline ArticleID & $:$ & 4685 \\
\hline \hline ArticleDOI & $:$ & $10.1186 /$ gb-spotlight-20030124-01 \\
\hline \hline ArticleCitationID & $:$ & spotlight-20030124-01 \\
\hline \hline ArticleSequenceNumber & $:$ & 37 \\
\hline \hline ArticleCategory & $:$ & Research news \\
\hline ArticleFirstPage & $:$ & 1 \\
\hline \hline ArticleLastPage & $:$ & 2 \\
\hline \hline & & RegistrationDate : 2003-1-24 \\
\hline ArticleHistory & $:$ & OnlineDate \\
\hline \hline ArticleCopyright & $:$ & BioMed Central Ltd2003-24 \\
\hline \hline ArticleGrants & $:$ & \\
\hline \hline ArticleContext & $:$ & 130594411 \\
\hline \hline
\end{tabular}




\section{Jonathan Weitzman}

Email: jonathanweitzman@hotmail.com

ATM, the product of the gene mutated in ataxia-telangiectasia (A-T), is involved in the cellular response to DNA damage and has been implicated in telomere maintenance. Atm mutant mice display modest aging and growth retardation defects compared to A-T patients. In an Advanced Online Publication in Nature Wong et al. describe studies in mice to assess the interaction between ATM and telomeres (Nature, 22 January 2003, DOI:10.1038/nature01385). They bred Atm-deficient mice with animals lacking the telomerase RNA component (Terc). Double knockout mice showed an increase in genomic instability and chromosomal fusions, and premature lethality. Cell proliferation defects were also observed in primary cells in culture and in several stem-cell populations in vivo. The interaction between telomeres and ATM, and the impaired stem-cell reserve, explains the multi-organ affects in A$\mathrm{T}$ patients.

\section{References}

1. ATM: genome stability, neuronal development, and cancer cross paths.

2. Nature, [http://www.nature.com]

This PDF file was created after publication. 